
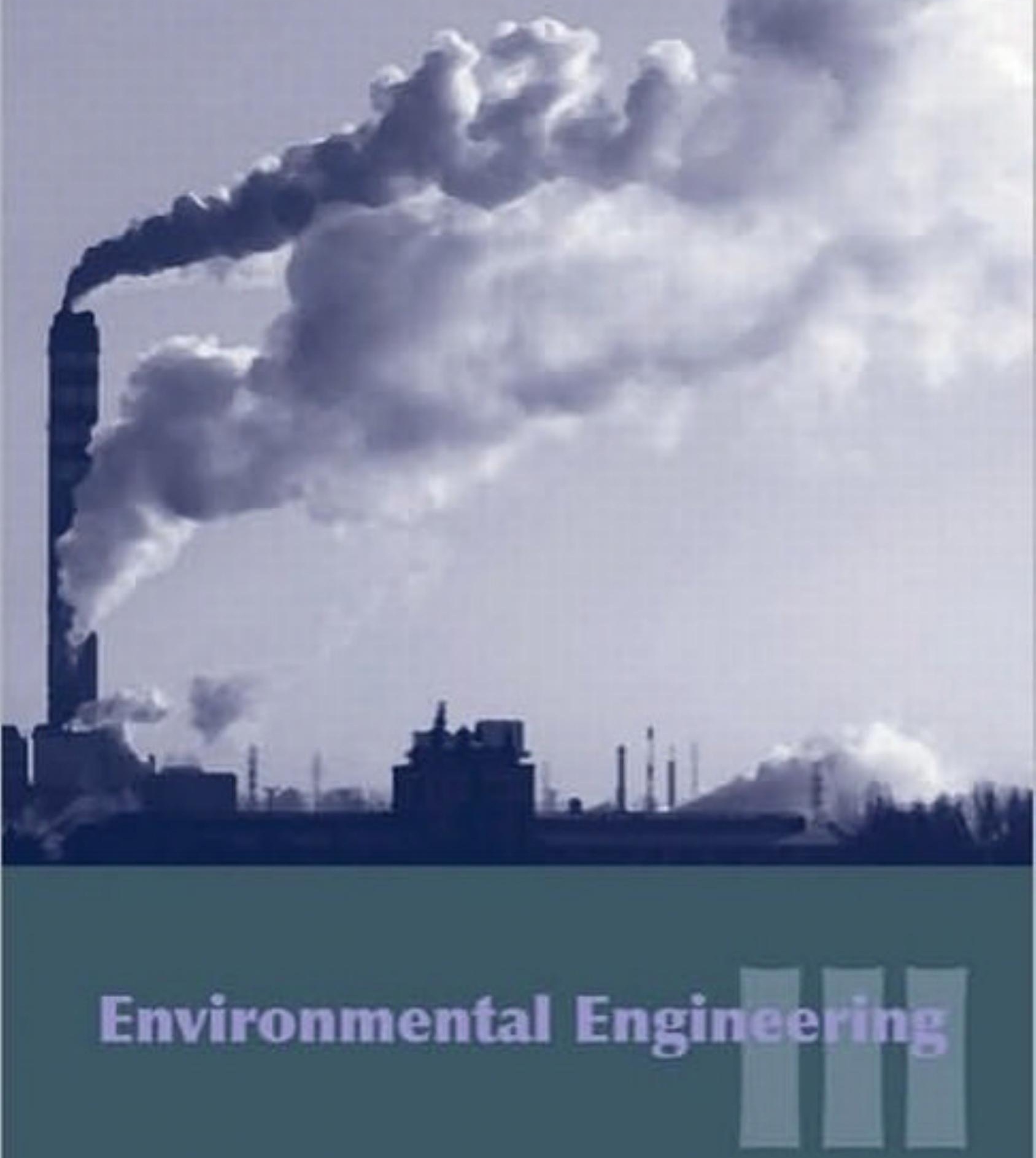

Lucjan Pawtowski Marzenna R. Dudzińska Artur Pawłowski 


\section{Environmental Engineering III}

\section{Edited by}

Lucjan Pawłowski, Marzenna R. Dudzińska \& Artur Pawłowski Institute of Environmental Protection Engineering,

Lublin University of Technology, Lublin, Poland

(cRC) CRC Press 
CRC Press/Balkema is an imprint of the Taylor \& Francis Group, an informa business

(C) 2010 Taylor \& Francis Group, London, UK

Typeset by MPS Ltd. (A Macmillan Company), Chennai, India

Printed and bound in Great Britain by Antony Rowe (A CPI Group Company), Chippenham, Wiltshire

All rights reserved. No part of this publication or the information contained herein may be reproduced, stored in a retrieval system, or transmitted in any form or by any means, electronic, mechanical, by photocopying, recording or otherwise, without written prior permission from the publisher.

Although all care is taken to ensure integrity and the quality of this publication and the information herein, no responsibility is assumed by the publishers nor the author for any damage to the property or persons as a result of operation or use of this publication and/or the information contained herein.

Published by: CRC Press/Balkema

P.O. Box 447, 2300 AK Leiden, The Netherlands

e-mail: Pub.NL@taylorandfrancis.com

www.crcpress.com - www.taylorandfrancis.co.uk - www.balkema.nl

ISBN: 978-0-415-54882-3 (Hardback)

ISBN: 978-0-203-84666-7 (eBook) 


\title{
Removal of microcystin-LR from water by ozonation
}

\author{
D. Szczukocki, B. M acioszek \& J. Dziegieć \\ D epartment of $G$ eneral and Inorganic C hemistry, U niversity of Lodz, Lodz, Poland
}

\begin{abstract}
A BSTRACT: In temperate climates, cyanobacteria (blue-green al gae) occur most frequently in summer, when the demand for recreational water is highest. B lue-green algae can produce toxins and are also responsible for the taste and odour of water, which significantly impairs its quality. Cyanotoxins are very dangerous substances which can intoxicate hepatocytes and the nervous system in humans and animals. To prevent such situations, it is very important to remove cyanotoxins from water effectively during the pretreatment process.

In the present study, the ozonation of water containing microcystin-LR was tested. We performed this research at the laboratory scale as well as in a pretreatment plant near the Sulejow artificial lake during several seasons.
\end{abstract}

Keywords: Cyanobacterial toxins, microcystin, ozonation, water pre-treatment.

\section{INTRODUCTION}

Cyanobacteria (blue-green algae) are organisms that have some characteristics of bacteria and some of al gae. They are similar to al gae in size and, unl ike other bacteria, they contain blue-green and green pigments and can perform photosynthesis. Pollution related to human activities, e.g. from agricultural runoff and inadequate sewage treatment, has led to excessive eutrophication (fertilization) of many water bodies. As a result, there is excessive proliferation of cyanobacteria in fresh water which has a considerable impact upon recreational water quality (as they are responsible for the taste and odour of water). In temperate climates, cyanobacterial dominance is most pronounced during the summer months, which coincides with the period when the demand for recreational water is the highest. The formation of cyanobacterial blooms is not a new phenomenon. The earliest reliable account of such blooms was at the end of the twelfth century (R essom et al. 1994).

Blue-green al gae produce several toxins, including neurotoxins, hepatotoxins, cylindrospermopsin and lipopolysaccharide endotoxins (Carmichael 1997). Toxic cyanobacteria are cosmopolitan. They have been recorded on every continent and about 50$75 \%$ of tested cyanobacterial blooms have been toxic (Codd 1995). Cyanobacteria have been implicated in various episodes of human and animal illnesses in Europe (Turner et al ., 1990), N orth and South A merica (Billings 1981, J ochimsen et al. 1998), A sia (Yu 1989, U eno et al. 1996), A frica (Zillberg 1966) and A ustralia (Falconer et al. 1983).

The type of cyanobacterial toxins most frequently found in fresh waters is microcystin-LR. This is a hepatotoxic peptide produced by a number of cyanobacterial genera, the most notable of which is the widespread



Figure 1. The structure of microcystin-LR.

Microcystis, from which the toxins take their name. The microcystin-LR is a cyclic heptapeptide (Figure 1). The molecule consists of a sevenmembered peptide ring which is made up of five non-protein amino acids and two protein amino acids: L eucine ( $L$ ) and A rginine (R) in positions 2 and 4 . The A dda side chain (position 5) is a key structural element necessary for biological activity. Separation of the A dda component from the cyclic peptide renders both components non-toxic (Carmichael 1992).

$M$ any strategies for the removal of microcystin$L R$ from water have been investigated. Conventional methods of water treatment (sedimentation, filtration, coagulation) have been reported to be ineffective (H offman 1976, Himberg et al. 1989).

A ctivated carbon can remove microcystin-L $R$, but doses have to be higher than those generally used in water treatment (Falconer et al. 1989). Nicholson 
et al. (1994) have reported that microcystin-LR can be removed by chlorination, but unfortunately chlorination of organic compounds can also cause adverse health effects in humans. Chlorine dioxide is not effective at those doses used in drinking water treatment. Hydrogen peroxide was found to be ineffective in toxin removal; used alone or with UV radiation, it can remove only about $50 \%$ of microcystin-LR after 30 minutes (Rositano \& Nicholson 1994). Ozone has been found to be most effective in oxidation of cellbound microcystin, if it is applied at a sufficiently high dose and with a sufficiently long contact time. Dissolved air flotation has been proposed in which the recycled water is saturated with ozone-rich air ( $B$ aron et al. 1997). Ozone-rich air has also been proposed for dispersed air flotation. These approaches might result in the reduction of extracellular toxins as well as enhanced cell removal (Chorus \& B artram 1999).

This paper presents the results obtained by the ozonation of microcystin-L $R$ in a water treatment plant near the Sulejow reservoir in Poland and at the laboratory scal e. The studies concerned with the processes of water production were conducted during three seasons with different ozone concentrations. This is the first research work on such a scale.

\section{MATERIALSAND METHODS}

To remove mechanical, organic and inorganic pollutants, the water samples were first filtered using a membrane and then concentrated using the solid phase extraction method. After sample preconcentration, microcolumns were rinsed with methanol. The al cohol fraction was evaporated at inert gas flow at room temperature. A fter evaporation the samples were dissolved in acetonitrile-ammonium acetate buffer $(74: 26 \mathrm{v} / \mathrm{v})$ filtered through a $0.45 \mathrm{~mm}$ filter and separated by RP-HPLC (M eriluoto 1997).

The concentration of ozone was determined by iodometric titration (Rakness et al. 1996).

\section{RESULTSAND DISCUSSION}

The changes in microcystin-LR concentrations (from an initial concentration of $16 \mathrm{mg} / \mathrm{dm}^{3}$ ) during the ozonation process at the laboratory scale can be found in Table 1.

The total toxin content was oxidized after the addition of about $0.01 \mathrm{mg} \mathrm{O}_{3}$ per $1 \mu \mathrm{g}$ of microcystin-LR. This result suggests that about 220 ozone molecules combine with one molecule of microcystin-LR. It is highly probable that the peptide ring of the toxin molecule is broken, but the mechanism has not yet been identified. The changes in microcystin-LR concentrations in relation to different ozone levels are given in Figure 2.

The amount of oxidizing microcystin-LR per unit of time, along with the given speed of ozone addition, does not correlate with the microcystin-LR
Table 1. Changes in microcystin-LR concentrations (from an initial concentration of $16 \mathrm{mg} / \mathrm{dm}^{3}$ ) during theozonation process (laboratory scale).

\begin{tabular}{lcc}
\hline $\begin{array}{l}\text { Time of } \\
\text { ozonation [s] }\end{array}$ & $\begin{array}{l}\text { Ozone } \\
\text { concentration in } \\
\text { sample [mg/dm }{ }^{3} \text { ] }\end{array}$ & $\begin{array}{l}\text { Mean yield of } \\
\text { microcystin-LR } \\
\text { residue [\%] }\end{array}$ \\
\hline 0 & 0.00 & 100 \\
5 & 0.06 & 78 \\
10 & 0.11 & 38 \\
11 & 0.12 & 32 \\
12 & 0.13 & 25 \\
13 & 0.14 & 17 \\
14 & 0.15 & 11 \\
15 & 0.16 & 5 \\
16 & 0.17 & 0 \\
\hline
\end{tabular}

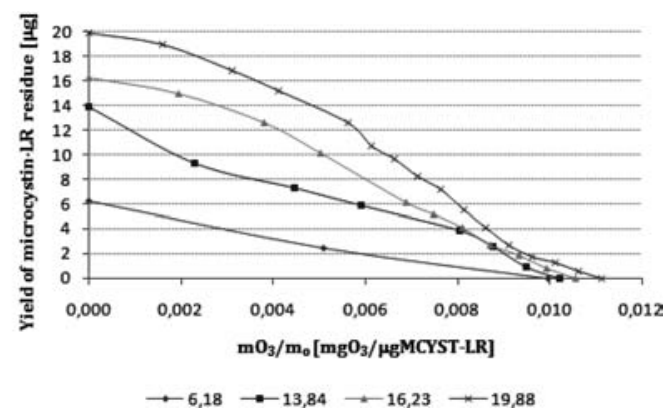

Figure 2. Changes in microcystin-LR concentrations in relation to ozone levels for different concentrations.

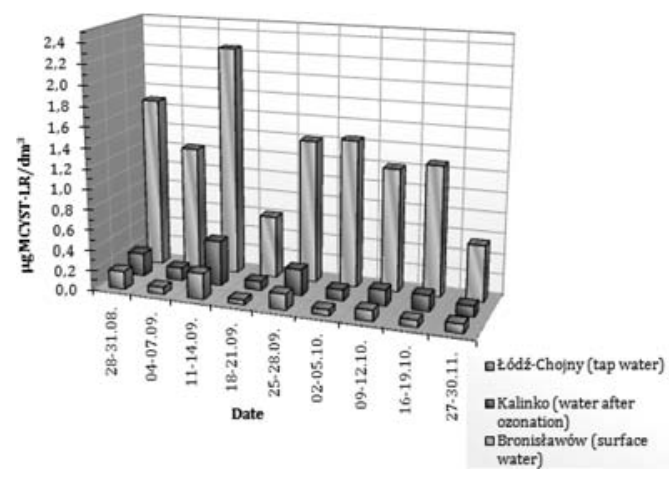

Figure 3. Concentrations of microcystin-LR in surface water, after ozonation in the Kalinko treatment plant, and in the Lodz-Chojny pumping station in the 2001 season.

concentrations in the solution. The microcystin-LR ozonation process is useful when cyanobacterial cells are removed.

The concentrations of microcystin-LR in surface water from the Sulejow artificial lake, after ozonation in a water treatment plant in Kalinko and at a final step in the L odz-Chojny pumping station, are given in Figures 3,4 and 5. 


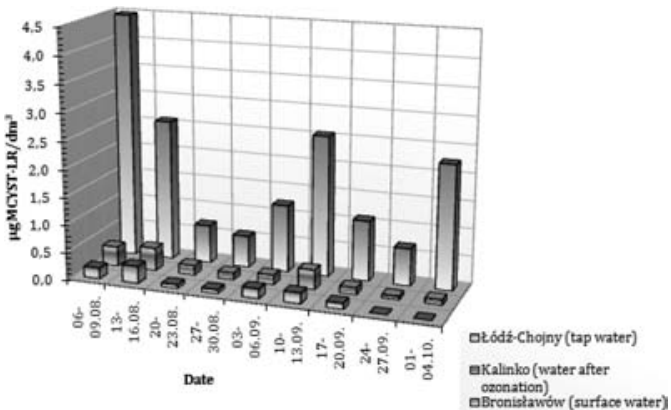

Figure 4. The concentrations of microcystin-LR in surface water, after ozonation in the Kalinko treatment plant, and in the Lodz-Chojny pumping station in the 2002 season.

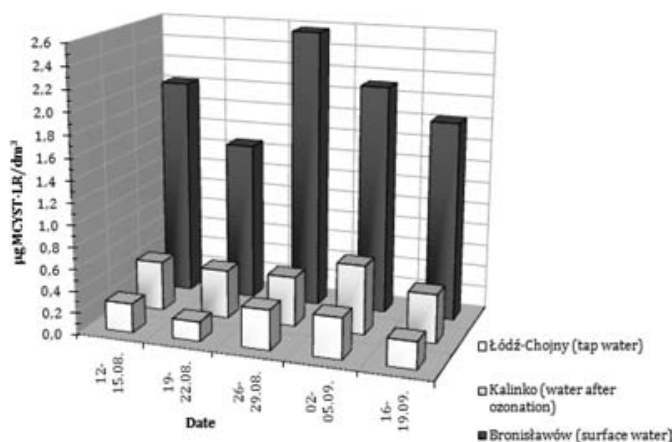

Figure 5. Concentrations of microcystin-LR in surface water, after ozonation in the Kalinko treatment plant, and in the Lodz-Chojny pumping station in the 2003 season.

Table 2. Doses of ozone used in the treatment system in Kalinko.

\begin{tabular}{lllc}
\hline & \multicolumn{2}{l}{ Ozone doses $\left[\mathrm{g} / \mathrm{m}^{3}\right]$} & \\
\cline { 2 - 3 } Season & Min. & M ax. & $\begin{array}{r}\text { M ean yield of } \\
\text { Ozonation [\%] }\end{array}$ \\
\hline 2001 & 1.5 & 3.0 & 90.8 \\
2002 & 1.4 & 3.5 & 92.1 \\
2003 & 1.3 & 1.7 & 85.7 \\
\hline
\end{tabular}

The ozone doses used in the treatment system in the $K$ alinko station can be found in Table 2 .

Toxic cyanobacterial blooms were observed between 2001 and 2003. M icrocystin-LR was found in surface water samples from the Sulejow reservoir even two months after the blooms had decayed.

\section{CONCLUSIONS}

The final efficiency of microcystin-LR removal in the ozonation process ranges between $82 \%$ and $100 \%$; this results in concentrations lower than the maximum recommended by WHO $\left(1 \mu \mathrm{g} / \mathrm{dm}^{3}\right)$. This efficiency can be obtained using ozone doses of $1.3-3.5 \mathrm{~g} \mathrm{O}_{3} / \mathrm{m}^{3}$ and a contact time of 35-48 mins.

A fter the ozonization process, water did not exhibit toxic properties. In spite of that, the products formed in the ozonolysis reaction may have adverse health effects. The toxicity of such substances is still under investigation.

Using a combination of ozone and UV light is possible. This method may enhance the efficiency of microcystin-LR removal but it has some disadvantages, e.g. it is a highly energy-consuming process. The application of such a technique may result in a higher cost for water production.

\section{ACKNOW LEDGEMENTS}

This study was supported by a grant from the M inistry of Faculty Science, Poland (project number N 523036 32/1348).

\section{REFERENCES}

Baron, J., Ionesco, N.M. \& Bacquet, G 1997. Combining flotation and ozonation the Flottazone process. In: Dissolved air flotation. Proceedings of an international conference. Chartered Institution of Water and Environment $M$ anagement. London.

Billings, W.H. 1981. Water-associated human illness in northeast Pennsylvania and its suspected association with bluegreen algae blooms. In W.W. Carmichael (ed.), The water environment: Algal toxins and health: 243-255. Plenum Press: New York.

Carmichael, W.W. 1997. The cyanotoxins. In Callow J.A. (ed.), Advances in botanical research. A cademic Press Inc.: San Diego 27: 211-256.

Carmichael W.W. 1992. Cyanobacteria secondary metabolites - the cyanotoxins. J. Appl. Bacteriol., 72: 445-459.

Chorus, I. \& Bartram, J. 1999. Toxic cyanobacteria in water: A guide to their public health consequences, monitoring and management., WHO. L ondon and N ew York.

Codd, G .A . 1995. Cyanobacterial toxins: Occurrence, properties and biological significance. Water Sci. Technol. 32(4): 149-156.

Falconer, I.R., B eresford, A.M.\& Runnegar, M.T.C. 1983. Evidence of liver damage by toxin from a bloom of the blue-green alga. M icrocystis aeruginosa, M ed. J. Aust. 1: 511-514.

Fal coner I.R ., R unnegar M .T.C., B uckley T., Huyn V.L ., B radshaw $P_{\text {. }}, 1989$, U sing activated carbon to remove toxicity from drinking water containing cyanobacterial blooms, J. Am. Water Works Assoc., vol. 81, no. 2, pp. 102-105.

Himberg, K., Keijola, A-M., Hiisvirta, L., Pyysalo, H. \& Sivonen, K. 1989. The effect of water treatment processes on the removal of hepatotoxins from Microcystis and Oscillatoria cyanobacteria: a laboratory study. Water Res. 23(8): 979-984.

Hoffmann, J.R.H. 1976. Removal of Microcystis toxins in water purification processes. Water S. Afr. 2(2): 58-60.

J ochimsen, E.M., Carmichael, W.W., A n, J.S., Cardo, D.M ., Cookson, S.T., Holmes, C.E.M., A ntunes, M.B.D., De M elo, D.A ., Lyra, T.M ., B aretto, V.S.T., A zevedo, S.M .F.O. \& J arvis, W.R. 1998. Liver failure and death after exposure to microcystins at a hemodialysis center in B razil. N. Engl. J. Med. 338: 873-878. 
M eriluoto J. 1997. Chromatography of microcystins. Anal. Chim. Acta 352: 277-298.

Nicholson, B.C., Rositano, J. \& Burch, M.D. 1994. Destruction of cyanobacterial peptide hepatotoxins by chlorine and chloramines. Water Res. 28(6): 1297-1303.

Rakness, K., Gordon, G., Langlais, B., M asschelein, W., M atsumoto, N., Richard, Y., Robson, M.\& Somiya, I. 1996. Guideline for measurement of ozone concentration in the process gas from an ozone integrator. Ozone Sci. Eng. 18: 209-229.

Ressom R., Soong F.S., Fitzgerald J., Turczynowicz L., El Saadi O., Roder D.M., M aynard T. \& Falconer I.R. 1994. $\mathrm{H}$ ealth effects of toxic cyanobacteria (blue-green algae). A ustralian Government Publishing Service: Canberra.

Rositano, J. \& Nicholson, B.C. 1994. Water treatment techniques for removal of cyanobacterial toxins from water. A ustralian Centre for Water Quality Research, Salisbury.
Turner P.C., Gammie A.J., Hollinrake K., Codd G .A., 1990, Pneumonia associated with contact with cyanobacteria, Br. Med. J ., vol. 300, pp. 1440-1441.

U eno, Y., Nagata, S., T sutsumi, T., H asegawa, A ., Watanabe, M .F., Park, H-D., Chen, G-C., Chen, G. \& Yu, S-Z., 1996, Detection of microcystins, a blue-green al gal hepatotoxin, in drinking water sampled in Haimen and Fusui, endemic areas of primary liver cancer in China, by highly sensitive immunoassay. Carcinogenesis 17(6): 1317-1321.

Yu, S-Z. 1989. Drinking water and primary liver cancer. In Z-Y. Tang, M -C.Wu, S-S.X ia (eds), P rimary liver cancer: 30-37. Springer-Verlag: Beijing.

Zillberg, B. 1966. Gastroenteritis in Salisbury European children - a five year study. Centr. Afr. J. Med. 12: 164-168. 